\title{
p53 Antibodies as a Diagnostic Marker for Cancer: A Meta-Analysis
}

\author{
Navid Sobhani ${ }^{1, *(\mathbb{D})}$, Giandomenico Roviello ${ }^{2}$, Alberto $\mathrm{D}^{\prime}$ Angelo ${ }^{3}$, Raheleh Roudi ${ }^{4} \mathbb{D}$, Praveen Kumar Neeli ${ }^{1}$ \\ and Daniele Generali ${ }^{5, *(1)}$
}

1 Department of Medicine, Section of Epidemiology and Population Sciences, Baylor College of Medicine, Houston, TX 77030, USA; praveenkumar.neeli@bcm.edu

2 Department of Health Sciences, University of Florence, 50121 Florence, Italy; giandomenico.roviello@unifi.it

3 Department of Biology and Biochemistry, University of Bath, Bath BA2 7AY, UK; ada43@bath.ac.uk

4 Department of Medicine, University of Minnesota Medical School, Minneapolis, MN 55455, USA; roudi002@umn.edu

5 Department of Medical, Surgical and Health Sciences, University of Trieste, Cattinara Hospital, Strada Di Fiume 447, 34149 Trieste, Italy

* Correspondence: navid.sobhani@bcm.edu (N.S.); dgenerali@units.it (D.G.)

Citation: Sobhani, N.; Roviello, G.; D'Angelo, A.; Roudi, R.; Neeli, P.K.; Generali, D. p53 Antibodies as a Diagnostic Marker for Cancer: A Meta-Analysis. Molecules 2021, 26, 6215. https://doi.org/10.3390/ molecules26206215

Academic Editor: Laura Cerchia

Received: 18 September 2021

Accepted: 11 October 2021

Published: 14 October 2021

Publisher's Note: MDPI stays neutral with regard to jurisdictional claims in published maps and institutional affiliations.

Copyright: (c) 2021 by the authors. Licensee MDPI, Basel, Switzerland. This article is an open access article distributed under the terms and conditions of the Creative Commons Attribution (CC BY) license (https:/ / creativecommons.org/licenses/by/ $4.0 /)$.
Abstract: Importance: The protein p53 is an unequivocal tumor suppressor that is altered in half of all cancers. The immune system produces systemic p53 autoantibodies (p53 Abs) in many cancer patients. Objective: This systemic review and meta-analysis focuses on the prognostic value of p53 Abs expressed in the serum of patients with solid tumors. Data Sources: All the clinical investigations were searched on PubMed from the first study dated 1993 until May 2021 (date of submission of the manuscript). Study Selection: Studies were included that met the following criteria: (1) participants with cancer; (2) outcome results expressed in relation to the presence of a p53 antibody; (3) a primary outcome (disease-free survival, overall survival or progression-free survival) expressed as hazard ratio (HR). The following exclusion criteria were used: (1) insufficient data available to evaluate outcomes; (2) animal studies; (3) studies with less than 10 participants. As a result, 12 studies were included in the analysis. Data Extraction and Synthesis: PRISMA guidelines were used for abstracting and assessing data quality and validity by three independent observers. The summary estimates were generated using a fixed-effect model (Mantel-Haenszel method) or a random-effect model (DerSimonian-Laird method), depending on the absence or presence of heterogeneity $\left(\mathrm{I}^{2}\right)$. Main Outcome(s) and Measure(s): The primary study outcome was to determine the prognostic value of p53 Abs from a large population of patients with solid tumors, as determined before data collection. Results: In total, 12 clinical studies involving 2094 patients were included in the meta-analysis, and it was determined that p53 Abs expression in the serum significantly correlated with poorer survival outcomes of cancer patients (95\% CI 1.48 [1.24, 1.77]; $p<0.00001$ ). Conclusions and Relevance: This is the first meta-analysis proving the diagnostic utility of p53-Abs for cancer patients in predicting poorer outcomes. The serum-p53 value (s-p53-value) may be useful for future theranostics.

Keywords: meta-analysis; p53; serum p53 antibodies; cancer survival prognostic biomarker

\section{Introduction}

The P53 protein is an unequivocal tumor suppressor mutated in almost half of human cancers [1-4]. It is autoregulated by MDM2, an E3 ubiquitin ligase [5,6].

Mice lacking MDM2 show embryonic lethality, while the dual presence of p53 and MDM2 can rescue lethality [7]. The p53 mutation in cancer (p53-mut) does not activate the expression of the E3 ligase. Consequently, degradation of p53 protein is not downmodulated [8]. High expression of p53 by cells recapitulates in T-cells the production of antibodies against mutant or wild type p53 [8]. On the other hand, in many cancer patients 
the p53-wt region is exposed and serum antibodies are generated against p53-wt. These can be detected by ELISA method. The roles of these antibodies are not yet clearly understood.

Prognostic biomarkers have a crucial role in measuring the progression of diseases from samples of patients, such as metastasis in cancer, and they can aid clinicians in intervening with more precise medical interventions. In addition to the common theory that in humans the loss of p53 increases genomic instability, this loss has been linked to the proliferation of the stem-cell characteristic that ultimately leads to highly aggressive cancers with invasive and metastatic properties. p53 antibodies (s-p53-Abs) are stably expressed in the sera of cancer patients, and could have an important prognostic application. Many clinical studies have assessed in cancer patients the correlation between the expression of s-p53-Abs with tumor invasiveness grades, metastasis and prognosis [9].

In our review, we performed a meta-analysis of the current literature, investigating the prognostic role of serum p53-Abs in cancer patients.

\section{Results}

After screening the article according to flow chart in Figure 1, 12 studies were selected [10-21]. A total of 2094 patients were included from these studies. The solid cancer patients were treated with adjuvant chemotherapy (such as cyclophosphamide, docetaxel, fluorouracil, epirubicin, methotrexate, and vinorelbine), anti-HER2 (trastuzumab, pertuzumab or lapatinib), endocrine therapy (such as goserelin, and tamoxifen), or combined treatment with Herceptin, chemotherapy, and the nonsteroidal anti-inflammatory drug celecoxib, also including radiotherapy or a surgical component in some cases (Tables 1 and 2). The pooled analysis revealed that s-p53-Abs is a negative prognostic factor (HR: 148 $[1.24,1.77] ; p<0.0001$, Figure 2$)$ in cancers. The analysis was performed using a randomeffects model (accounting for effect size heterogeneity; $\mathrm{I}^{2}=19 \%$ ).

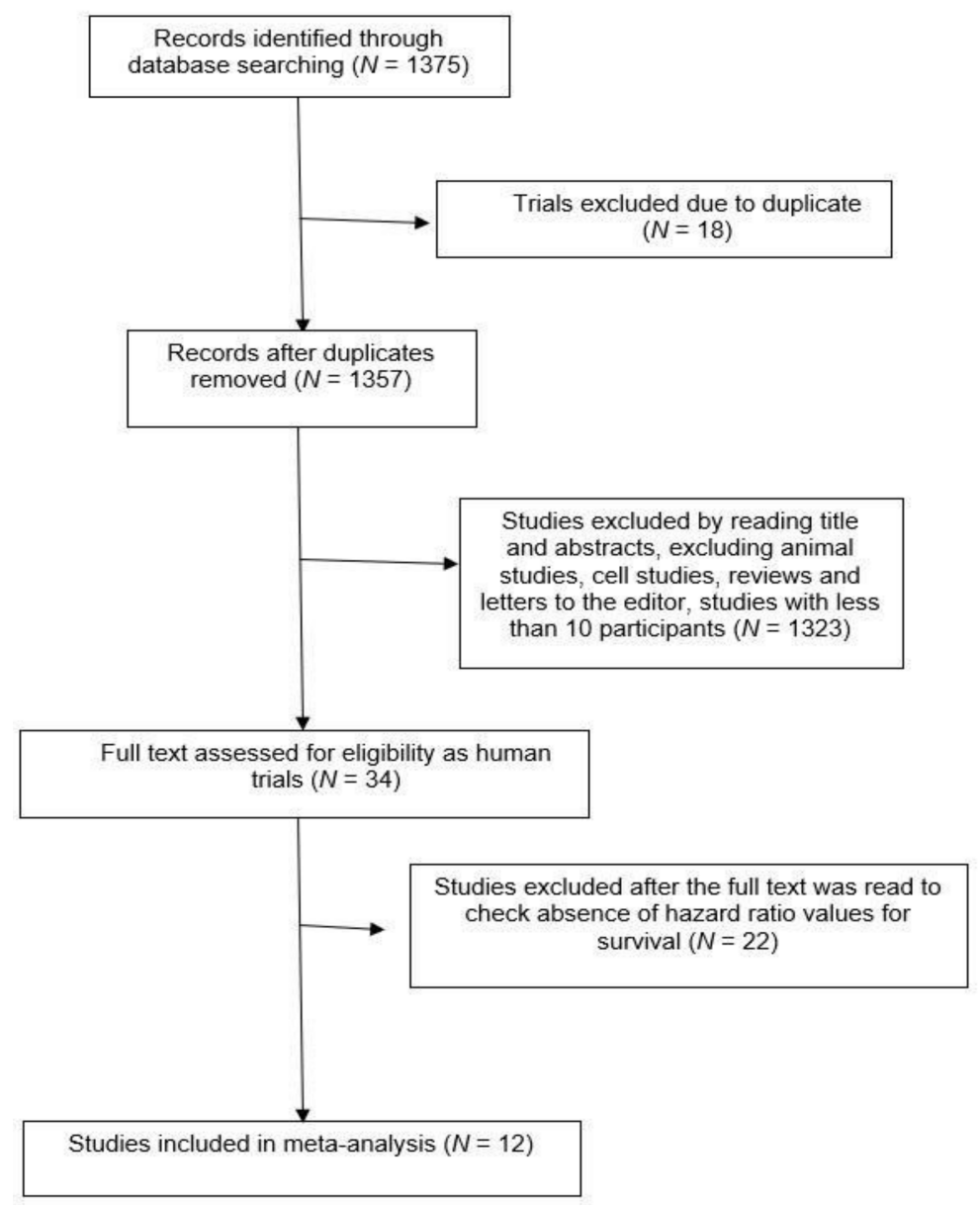

Figure 1. Flowchart of literature research strategy. 


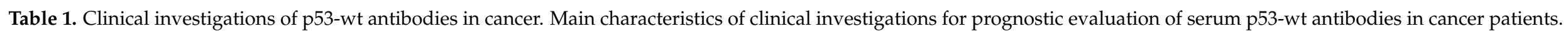

\begin{tabular}{|c|c|c|c|c|c|c|c|}
\hline $\begin{array}{c}\text { Study } \\
\text { Reference }\end{array}$ & Patients & Methods & Inclusion/Exclusion Criteria & Intervention & Follow-Up Time & Prognostic Value of s-p53-Abs & Type of Study \\
\hline [10] & $\begin{array}{l}76 \text { patients with } \\
\text { transitional urinary } \\
\text { bladder cell } \\
\text { carcinoma }\end{array}$ & $\begin{array}{l}\text { S-p53-Abs } \\
\text { ELISA. Antibodies for } \\
\text { p53-wt } \\
\text { 184 CRC patients }\end{array}$ & $\begin{array}{l}\text { Inclusion: transitional cell } \\
\text { urinary bladder cancer } \\
\text { Exclusion: secondary organ } \\
\text { cancer; immunodeficiency state; } \\
\text { ages over 90; other urinary } \\
\text { bladder tumors. }\end{array}$ & $\begin{array}{c}\text { Surgery (TUR) } \\
\text { Surgery + } \\
\text { chemotherapy + } \\
\text { radiotherapy } \\
\text { (advanced stage) }\end{array}$ & 34 months & $\begin{array}{c}\text { There was an association between the } \\
\text { presence of s-p53-Abs and tumor p53 gene } \\
\text { overexpression }(p=0.001) \text {. }\end{array}$ & Prospective \\
\hline [11] & $\begin{array}{c}184 \text { CRC patients. } \\
\text { Dukes' stage: } \\
\text { A }(n=31) ; \text { B }(n=84) ; \\
\text { C }(n=41) ; \mathrm{D}(n=28)\end{array}$ & $\begin{array}{l}\text { S-p53-Abs } \\
\text { ELISA. Antibodies for } \\
\text { p53-wt } \\
\text { 184 CRC patients }\end{array}$ & Inclusion: primary colon cancer & $\begin{array}{l}\text { Routine Biopsy } \\
\text { Surgery }\end{array}$ & 96 months & $\begin{array}{l}\text { p53-Abs correlated with shorter survival } \\
\qquad(p=0.02)\end{array}$ & Retrospective \\
\hline [12] & 170 CRC patients & $\begin{array}{l}\text { S-p53Ab, CEA } \\
\text { ELISA. Antibody for } \\
\text { p53-wt }\end{array}$ & $\begin{array}{l}\text { Inclusion: primary colon cancer } \\
\text { Exclusion: previous } \\
\text { radiotherapy or chemotherapy }\end{array}$ & $\begin{array}{l}\text { Surgery (resected tumor } \\
\text { specimen) }\end{array}$ & $\begin{array}{l}93.6 \text { months } \\
\text { (median value) }\end{array}$ & $\begin{array}{l}\text { Positivity for s-p53Ab in CRC did not } \\
\text { correlate with overall survival. } \\
\text { Kaplan-Meier analysis revealed significant } \\
\text { differences between patients with elevated } \\
\text { s-p53Ab and CEA and those with elevated } \\
\text { levels of either one or neither of these } \\
\text { factors }(p<0.001) .\end{array}$ & Retrospective \\
\hline [13] & 208 GC patients & $\begin{array}{c}\text { S-p53Ab } \\
\text { Detected with } \\
\text { anti-p53 detection kit } \\
\text { MESACUP anti-p53 } \\
\text { Test } \\
\text { Antibody for p53-wt }\end{array}$ & $\begin{array}{c}\text { Inclusion: Histologically } \\
\text { confirmed GC } \\
\text { Exclusion: previously } \\
\text { chemotherapy, radiotherapy } \\
\text { and those who died within } 30 \\
\text { days after surgery }\end{array}$ & Surgery & 34 months & $\begin{array}{l}\text { Did not observe any significant correlation } \\
\text { between S-p53Ab in GC and overall } \\
\text { survival (hazard ratio }(\mathrm{HR})=2.052 ; 95 \% \\
\text { confidence interval CI) }=0.891-4.726 ; \\
\quad p=0.091) \\
\text { Conversely, Cox regression analysis } \\
\text { revealed that a high level of CA19-9 was } \\
\text { an independent prognostic factor for GC } \\
\text { (hazard ratio (HR) }=3.864 ; 95 \% \text { confidence } \\
\text { interval }(\mathrm{CI})=1.248-11.959 ; p=0.019) .\end{array}$ & Retrospective \\
\hline [14] & 231 SCLC patients & $\begin{array}{l}\text { S-p53-Abs } \\
\text { ELISA. Antibodies for } \\
\text { p53-wt }\end{array}$ & Inclusion: primary SCLC & $\begin{array}{c}\text { Surgery } \\
\text { Chemotherapy (227 out } \\
\text { of } 231 \text { patients) }\end{array}$ & $\begin{array}{l}3 \text { months } \\
\text { (at least) }\end{array}$ & $\begin{array}{l}\text { High levels of p53-Abs correlated with } \\
\text { worse survival prospects compared to } \\
\text { patients with lower levels of the antibodies } \\
\qquad(p=0.02) .\end{array}$ & Retrospective \\
\hline
\end{tabular}


Table 1. Cont.

\begin{tabular}{|c|c|c|c|c|c|c|c|}
\hline $\begin{array}{l}\text { Study } \\
\text { Reference }\end{array}$ & Patients & Methods & Inclusion/Exclusion Criteria & Intervention & Follow-Up Time & Prognostic Value of s-p53-Abs & Type of Study \\
\hline [15] & 80 HCC patients & $\begin{array}{l}\text { S-p53-Abs } \\
\text { ELISA. Antibodies for } \\
\text { p53-wt }\end{array}$ & $\begin{array}{c}\text { Inclusion: Cytohistological of } \\
\text { AFP level-based diagnosis of } \\
\text { HCC }\end{array}$ & $\begin{array}{c}\text { Percutaneous injection } \\
(21) \\
\text { Surgery (15) } \\
\text { Radiofrequency } \\
\text { interstitial ablation (10) } \\
\text { Chemotherapy (4) } \\
\text { TACE (8) } \\
\text { Combinational } \\
\text { treatment (5) } \\
\text { No treatment (17) }\end{array}$ & 36 months & $\begin{array}{l}\text { Anti-p53 was not useful as a } \\
\text { prognostic factor. }\end{array}$ & Retrospective \\
\hline [16] & 244 CRC patients & $\begin{array}{l}\text { CEA, CA19-9, } \\
\text { S-P53Ab } \\
\text { Antibody for p53-wt }\end{array}$ & $\begin{array}{l}\text { Inclusion: preoperative CEA, } \\
\text { CA-19 and S-P53Ab. Primary } \\
\text { tumor diagnosis }\end{array}$ & $\begin{array}{l}\text { Surgery (colectomy plus } \\
\text { lymph nodes dissection) } \\
\text { Chemotherapy (in case } \\
\text { of CRC recurrence) }\end{array}$ & $\begin{array}{l}33.8 \text { months } \\
\text { (median) }\end{array}$ & $\begin{array}{l}\text { S-P53Ab had no power to predict the } \\
\text { prognosis }(p=0.786) \text {. } \\
\text { Combined CEA and CA19-9 positivity was } \\
\text { an exclusive independent prognostic factor } \\
(p=0.034) .\end{array}$ & Retrospective \\
\hline [17] & 97 SCLC patients & $\begin{array}{l}\text { S-p53-Abs } \\
\text { ELISA. Antibodies for } \\
\text { p53-wt }\end{array}$ & $\begin{array}{l}\text { Inclusion: newly and proven } \\
\text { diagnosed lung cancer }\end{array}$ & $\begin{array}{c}\text { Bronchial biopsy } \\
\text { Chemotherapy } \\
\text { (cisplatin, etoposide, } \\
\text { doxorubicin, } \\
\text { cyclophosphamide) } \\
\text { Radiotherapy for those } \\
\text { with brain metastasis }\end{array}$ & $\begin{array}{l}18.1 \text { months } \\
\text { (median) }\end{array}$ & $\begin{array}{l}\text { Patients with limited-stage SCLC and } \\
\text { p53-Ab had a median survival time of } 10 \\
\text { months, whereas limited-stage SCLC } \\
\text { patients without p53-Ab had a 17-month } \\
\text { median survival time }(p=0.014) .\end{array}$ & Prospective \\
\hline [18] & $\begin{array}{c}133 \text { esophageal } \\
\text { squamous cell } \\
\text { carcinoma (ESCC) } \\
\text { patients }\end{array}$ & $\begin{array}{l}\text { S-p53Ab, SCC-Ag, } \\
\text { CEA } \\
\text { Antibody for p53-wt }\end{array}$ & $\begin{array}{c}\text { Inclusion: histologically } \\
\text { confirmed ESCC } \\
\text { Exclusion: patients who died } \\
\text { after } 30 \text { days after treatment and } \\
\text { those who had preoperative } \\
\text { radiotherapy }\end{array}$ & Surgery & $\begin{array}{l}36 \text { months } \\
\text { (median) }\end{array}$ & $\begin{array}{c}\text { S-p53Ab was detected in } 39.1 \% \text { ( } 52 \text { out of } \\
133 \text { ) of patients with ESCC, including } \\
40.0 \% \text { ( } 20 \text { out of } 50 \text { ) of patients with } \\
\text { early-stage ESCC }(p=0.009)\end{array}$ & Retrospective \\
\hline [22] & $\begin{array}{l}201 \text { lung cancer } \\
\text { patients }\end{array}$ & $\begin{array}{l}\text { S-p53 antibodies by } \\
\text { ELISA }\end{array}$ & Inclusion: Primary lung cancer & $\begin{array}{c}\text { Surgery } \\
\text { Chemotherapy (Stage } \\
\text { IIIB and IV) } \\
\text { Radiotherapy (if } \\
\text { required) }\end{array}$ & 63 months & $\begin{array}{l}\text { Patients with lower levels of p53Abs } \\
\text { survived significantly longer than patients } \\
\text { with higher levels of p53Abs }(p=0.049) \text {. }\end{array}$ & Retrospective \\
\hline [19] & $\begin{array}{l}1487 \text { esophageal } \\
\text { squamous cell } \\
\text { carcinoma }\end{array}$ & $\begin{array}{l}\text { S-p53 antibodies by } \\
\text { ELISA }\end{array}$ & $\begin{array}{l}\text { Inclusion: radical surgery with } \\
\text { no neoadjuvant treatment }\end{array}$ & Esophagectomy & $\begin{array}{l}42 \text { months } \\
\text { (median) }\end{array}$ & $\begin{array}{l}\text { s-p53-Ab positive status was not } \\
\text { significantly associated with poor overall } \\
\text { survival }\end{array}$ & Retrospective \\
\hline
\end{tabular}


Table 1. Cont.

\begin{tabular}{|c|c|c|c|c|c|c|c|}
\hline $\begin{array}{c}\text { Study } \\
\text { Reference }\end{array}$ & Patients & Methods & Inclusion/Exclusion Criteria & Intervention & Follow-Up Time & Prognostic Value of s-p53-Abs & Type of Study \\
\hline [20] & $\begin{array}{l}160 \text { hepatocellular } \\
\text { carcinoma }\end{array}$ & $\begin{array}{c}\text { Six hepatocellular } \\
\text { carcinoma-associated } \\
\text { antigens, including } \\
\text { Sui1, p62, RalA, p53, } \\
\text { NY-ESO-1, and c-myc } \\
\text { antibodies by ELISA } \\
\text { (TAA Panel) }\end{array}$ & $\begin{array}{c}\text { Inclusion: histologically proven } \\
\text { HCC } \\
\text { Exclusion: coexisting or } \\
\text { metachronous cancer within } 5 \\
\text { disease-free years }\end{array}$ & Surgery & 60 months & $\begin{array}{l}\text { The positivity for the TAA panel was } \\
\text { independently associated with poor } \\
\text { prognosis }(p=0.030)\end{array}$ & Retrospective \\
\hline [21] & 72 gastric cancers & $\begin{array}{l}\text { S-p53 antibodies by } \\
\text { ELISA }\end{array}$ & $\begin{array}{c}\text { Inclusion: primary gastric } \\
\text { cancer } \\
\text { Exclusion: previous } \\
\text { chemotherapy; coexisting cancer }\end{array}$ & Surgery & $\begin{array}{l}32 \text { months } \\
\text { (median) }\end{array}$ & $\begin{array}{l}\text { Overall survival was not associated with } \\
\text { the antibodies }\end{array}$ & Retrospective \\
\hline [23] & $\begin{array}{l}105 \\
\text { esophageal squamous } \\
\text { cell carcinoma }\end{array}$ & $\begin{array}{l}\text { S-p53 antibodies by } \\
\text { ELISA }\end{array}$ & $\begin{array}{l}\text { Inclusion: primary esophageal } \\
\text { squamous cell carcinoma } \\
\text { Exclusion: metastatic disease; } \\
\text { neoadjuvant therapy }\end{array}$ & Surgery & $\begin{array}{l}35 \text { months } \\
\text { (median) }\end{array}$ & $\begin{array}{l}\text { While seropositive patients did not } \\
\text { demonstrate significant poor overall } \\
\text { survival, high-titer patients demonstrated } \\
\text { significant poor overall survival based on } \\
\text { the multivariate analysis }(p<0.001) \text {. }\end{array}$ & Retrospective \\
\hline
\end{tabular}

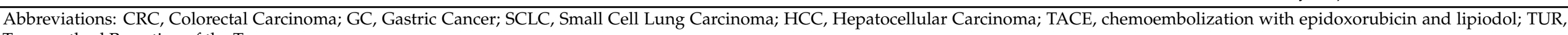
Transurethral Resection of the Tumor. 
Table 2. Clinical investigations of p53-mut antibodies in cancer. Main characteristics of clinical investigations for prognostic evaluation of serum p53-mut antibodies in cancer patients.

\begin{tabular}{|c|c|c|c|c|c|}
\hline $\begin{array}{c}\text { Study } \\
\text { Reference }\end{array}$ & Patients & Methods & Prognostic Value of s-p53-Abs & Type of Study & Inference \\
\hline [24] & $\begin{array}{l}111 \text { gastric } \\
\text { carcinoma } \\
\text { patients }\end{array}$ & $\begin{array}{l}\text { S-p53-Abs } \\
\text { Levels of } \\
\text { p53-mut were } \\
\text { determined with a } \\
\text { selective, quantitative } \\
\text { ELISA kit }\end{array}$ & $\begin{array}{l}\text { The survival time of serum-positive } \\
\text { patients was significantly longer than } \\
\text { that of patients with low / negative } \\
\text { serum levels, with a survival rate of } \\
41.2 \% \text { and } 14.9 \% \text {, respectively, over } 48 \\
\text { months }(p<0.05) \text {. }\end{array}$ & Retrospective & $\begin{array}{l}\text { Significant correlation } \\
\text { seen between levels of } \\
\text { S-p53-mut Abs and } \\
\text { patient survival rate }\end{array}$ \\
\hline [25] & $\begin{array}{l}104 \text { ovarian } \\
\text { cancer patients }\end{array}$ & $\begin{array}{l}\text { S-p53-Abs } \\
\text { ELISA. Antibodies } \\
\text { against p53K132Q } \\
\text { (c.394A > C). }\end{array}$ & $\begin{array}{l}\text { Overall survival (OS) was } \\
\text { significantly higher for patients with } \\
\text { antibodies to mutant p53 when } \\
\text { compared with patients without p53 } \\
\text { antibodies }(p=0.01) \text {. }\end{array}$ & Retrospective & $\begin{array}{c}\text { OS is significantly } \\
\text { increased in advanced } \\
\text { stage ovarian cancer } \\
\text { patients with antibodies } \\
\text { to p53 }\end{array}$ \\
\hline [17] & $\begin{array}{l}134 \text { lung cancer } \\
\text { patients }\end{array}$ & $\begin{array}{l}\text { S-p53-Abs by } \\
\text { Immunofluorescence. } \\
\text { Antibodies against } \\
\text { p53 R273H (c.818G > } \\
\text { A) by ELISA. }\end{array}$ & $\begin{array}{l}\text { Presence of anti-p53 autoantibodies is } \\
\text { almost exclusively linked to the } \\
\text { presence of malignant disease. }\end{array}$ & Retrospective & $\begin{array}{l}\text { Presence of anti-p53 Abs } \\
\text { had a significant } \\
\text { correlation with shorter } \\
\text { survival in NSCLC. }\end{array}$ \\
\hline [26] & $50 \mathrm{BC}$ patients & $\begin{array}{l}\text { S-p53-Abs } \\
\text { ELISA. Antibodies } \\
\text { against p53R273H } \\
(\text { c. } 818 \mathrm{G}>\mathrm{A}) .\end{array}$ & $\begin{array}{l}\text { s-p53-Abs were higher in } B C \text { patients } \\
\text { with high risk vs. patients with low } \\
\text { risk. The difference was not } \\
\text { statistically significant }(p=0.15)\end{array}$ & Retrospective & $\begin{array}{l}\text { Presence of s-p53-Abs } \\
\text { showed higher risk for } \\
\text { BC patients. }\end{array}$ \\
\hline
\end{tabular}

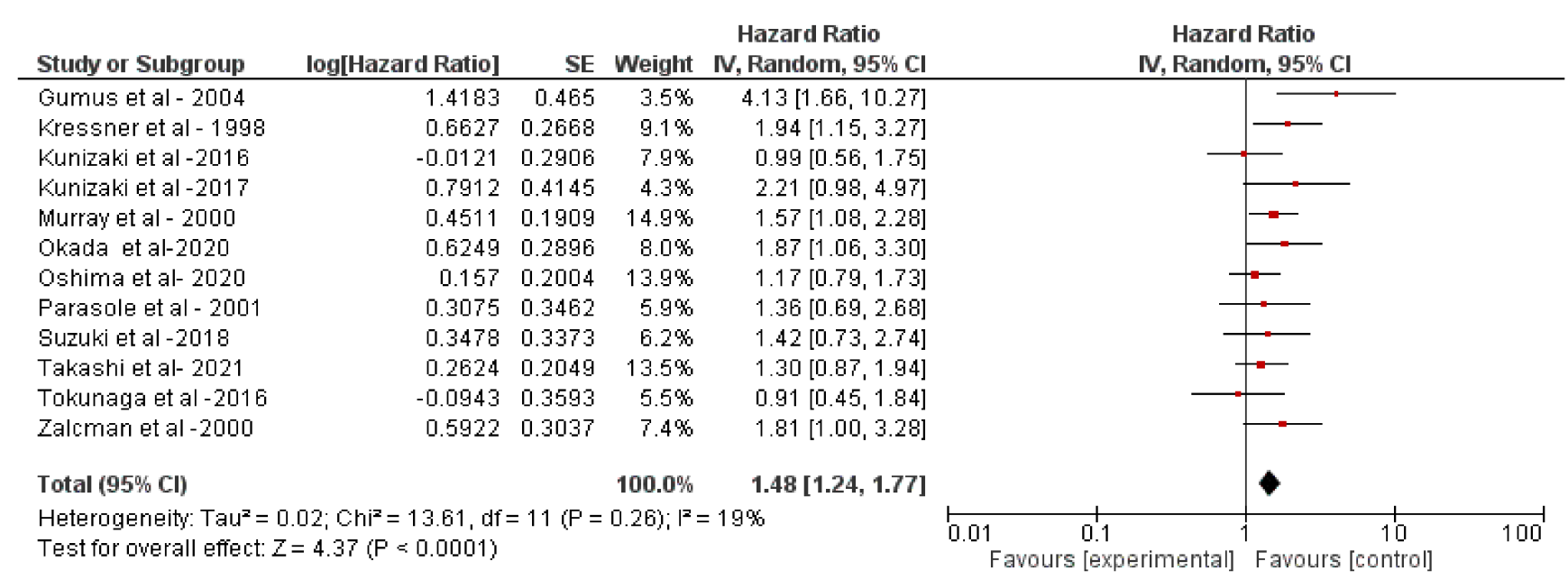

Figure 2. Meta-analysis of serum p53-antibodies. The prognostic value of p53 antibodies in the sera of cancer patients from eight clinical investigations was investigated in this meta-analysis.

The funnel plot (Figure 3) of the included studies showed a symmetric funnel plot and no significant publication bias was identified. 


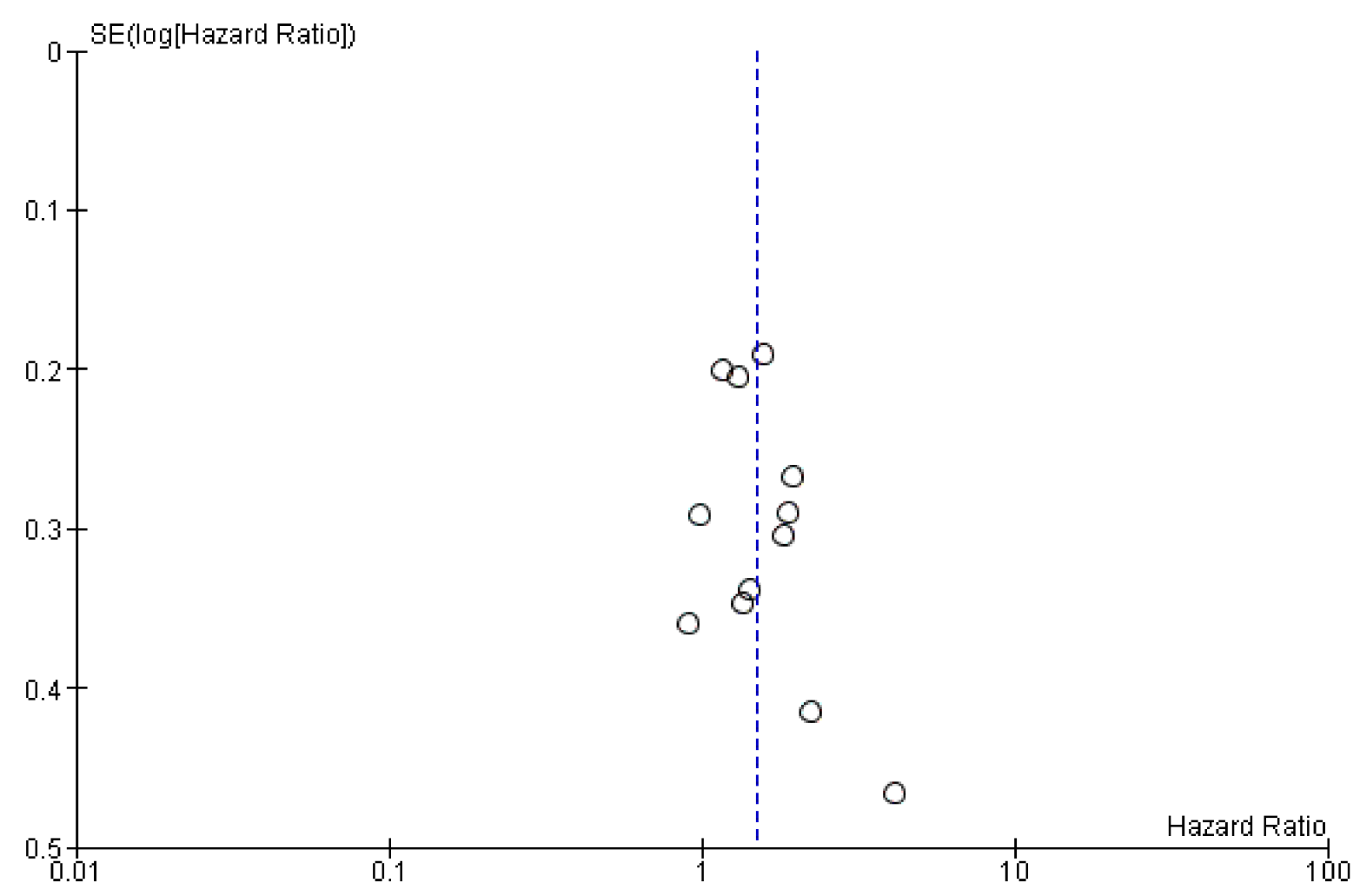

Figure 3. The funnel plot of included studies.

\section{Discussion}

The meta-analysis showed that high levels of p53 antibodies significantly correlated with worse clinical outcomes. However, our study had some limitations. First, the retrospective nature of the study was intrinsically susceptible to biases. Second, different forms of solid tumors were included pre- or post-treatment with various types of therapies, as the typology requirements were at different stages. Consequently, in our analysis patients were observed independently of treatment and tumor type because of the relatively low number of randomized studies at our disposal. Third, there was a lack of follow-up with patients from different clinical trials. Thus, differences in survival probability may have been influenced by the durations of the studies. This may have given rise to different age populations, which could ultimately have affected the data. All these variables may ultimately have influenced the results.

As medicine advances, studies involving greater numbers of patients could help to evaluate the impact of our findings and treatment response.

In summary, p53 is a well-established tumor suppressor, and its absence is commonly found in patients diagnosed with cancer. The p53 protein has been demonstrated to be absent or mutated in approximately one out of two malignancies. It is known that p53wt cancers have a better prognosis compared to p53-mut cancers. Our data are not in contradiction with this notion. Although both mutated and wild type p53 antibodies can be detected in cancer patients, their role is still controversial and a matter for debate. Recently, a few studies have reported that these antibodies are statistically associated with the survival of patients diagnosed with different malignancies. To the best of our knowledge, our meta-analysis is original and is the first study gathering p53 (wild type/mutated) antibody data generated from 1993 thus far. Overall, the investigation includes 12 studies and a total of 2094 patients. 


\section{Materials and Methods}

The studies were identified according to the following inclusion criteria: (1) participants with cancer; (2) outcome results expressed in relation to the presence of a p53 antibody; (3) a primary outcome (disease-free survival, overall survival or progression-free survival) expressed as hazard ratio (HR). The following exclusion criteria were used: (1) insufficient data available to evaluate outcomes; (2) animal studies; (3) studies with less than 10 participants.

Two independent researchers revised the included studies, and all potential disputes that could have arisen were evaluated with the corresponding author.

The summary estimates were generated using a fixed-effect model (Mantel-Haenszel method) [27] or a random-effect model (DerSimonian-Laird method) [28] depending on the absence or presence of heterogeneity $\left(\mathrm{I}^{2}\right)$. A subgroup analysis was performed to highlight any differences between studies in terms of Overall Survival (OS), Disease-Free Survival (DFS), Progression-Free Survival (PFS), as summarized in Table 1.

When we used the keywords "p53 antibodies in early cancer", p53 antibodies in metastatic cancer", "p53 antibodies impact on cancer progression", the PubMed search yielded 1375 potentially relevant articles. Studies as duplicates, animal studies, cellular studies, or letters to the editor or reviews were excluded. After viewing the titles and abstracts, the full texts of 34 studies were retrieved and 12 studies [10-21] were included in the analysis because they had the hazard ratio available for survivals (Tables 1 and 2) as summarized in the flow chart of Figure 1.

\section{Conclusions}

We observed that serum antibodies generated in the blood of cancer patients against p53 (and mostly p53-wt) were deleterious. Given the straightforward detection in blood of p53 antibodies as a biomarker for cancer survival, as summarized in a simple workflow in Figure 4, these antibodies, together with other biomarkers, potentially constitute a valid method for prediction of cancer patients' survival outcomes. The correlation could also play an important role for targeted therapies involving a cancer-suppressing p53 pathway.

\section{Serum antibodies as diagnostic marker for cancer}

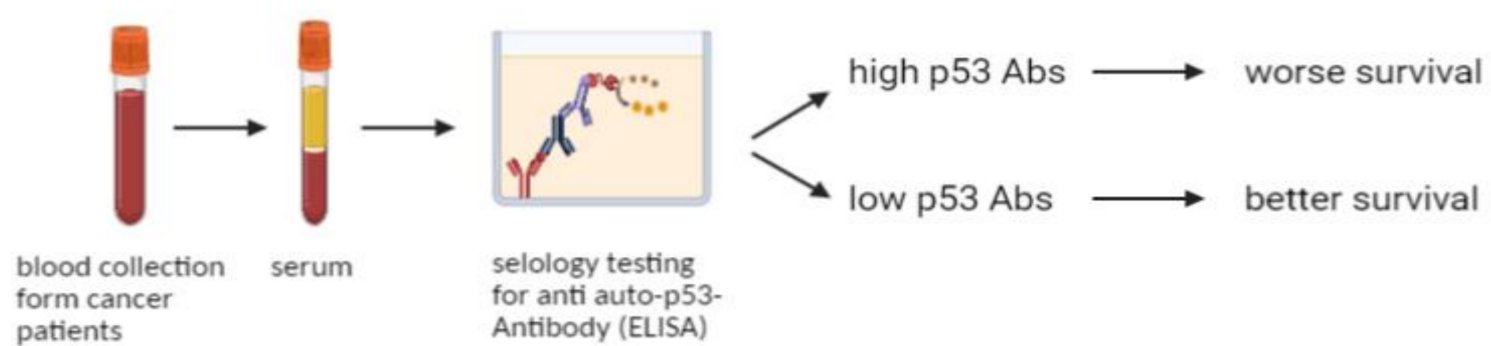

Figure 4. Schematic representation of the significance of serological biomarker p53 antibodies (p53Abs) in prediction of cancer survival.

\section{Competing Interests}

The authors have no relevant affiliations or financial involvement with any organization or entity with a financial interest in, or financial conflict with, the subject matter or materials discussed in the manuscript. This includes employment, consultancies, honoraria, stock ownership or options, expert testimony, grants or patents received or pending, or royalties. No writing assistance was utilized in the production of this manuscript.

Author Contributions: G.R. and N.S. conceived, designed and planned the study. G.R. and N.S. acquired data and produced original drafts and figures. G.R. conducted statistical analysis of the data. G.R. and N.S. drafted the manuscript. P.K.N., R.R., D.G. and A.D. revised and improved 
the manuscript's content and visualization. All authors helped interpret the results and draft the manuscript. All authors revised and reviewed this article. All authors have read and agreed to the published version of the manuscript.

Funding: This research received no external funding.

Institutional Review Board Statement: Not applicable for studies directly not involving humans or animals. Also as to ethics approval, the article does not contain any direct studies with human participants or animals performed by any of the authors.

Informed Consent Statement: Not applicable for studies directly not involving humans.

Data Availability Statement: All relevant data are within the paper.

Acknowledgments: This research was supported by Mednote, spin-off-University of Trieste-Mozart Program.

Conflicts of Interest: The authors declare no conflict of interest.

Sample Availability: Samples of the compounds are not available from the authors.

\section{References}

1. Hollstein, M.; Sidransky, D.; Vogelstein, B.; Harris, C.C. p53 Mutations in Human Cancers. Science 1991, 253, 49-53. [CrossRef]

2. Kandoth, C.; McLellan, M.D.; Vandin, F.; Ye, K.; Niu, B.; Lu, C.; Xie, M.; Zhang, Q.; McMichael, J.F.; Wyczalkowski, M.A.; et al. Mutational Landscape and Significance across 12 Major Cancer Types. Nature 2013, 502, 333-339. [CrossRef]

3. Juven, T.; Barak, Y.; Zauberman, A.; George, D.L.; Oren, M. Wild Type p53 Can Mediate Sequence-Specific Transactivation of an Internal Promoter within the mdm2 Gene. Oncogene 1993, 8, 3411-3416.

4. $\quad \mathrm{Wu}$, X.; Bayle, J.H.; Olson, D.; Levine, A.J. The p53-Mdm-2 Autoregulatory Feedback Loop. Genes Dev. 1993, 7, $1126-1132$. [CrossRef] [PubMed]

5. Momand, J.; Zambetti, G.P.; Olson, D.C.; George, D.; Levine, A.J. The Mdm-2 Oncogene Product Forms a Complex with the p53 Protein and Inhibits p53-Mediated Transactivation. Cell 1992, 69, 1237-1245. [CrossRef]

6. Chen, J.; Wu, X.; Lin, J.; Levine, A.J. Mdm-2 Inhibits the G1 Arrest and Apoptosis Functions of the p53 Tumor Suppressor Protein. Mol. Cell. Biol. 1996, 16, 2445-2452. [CrossRef] [PubMed]

7. Jones, S.N.; Roe, A.E.; Donehower, L.A.; Bradley, A. Rescue of Embryonic Lethality in Mdm2-Deficient Mice by Absence of p53. Nature 1995, 378, 206-208. [CrossRef] [PubMed]

8. Lukashchuk, N.; Vousden, K.H. Ubiquitination and Degradation of Mutant p53. Mol. Cell. Biol. 2007, 27, 8284-8295. [CrossRef]

9. Sobhani, N.; D’Angelo, A.; Wang, X.; Young, K.H.; Generali, D.; Li, Y. Mutant p53 as an Antigen in Cancer Immunotherapy. Int. J. Mol. Sci. 2020, 21, 4087. [CrossRef]

10. Gumus, E.; Erdamar, S.; Demirel, G.; Horasanli, K.; Kendirci, M.; Miroglu, C. Association of Positive Serum Anti-p53 Antibodies with Poor Prognosis in Bladder Cancer Patients. Int. J. Urol. 2004, 11, 1070-1077. [CrossRef]

11. Kressner, U.; Glimelius, B.; Bergström, R.; Påhlman, L.; Larsson, A.; Lindmark, G. Increased Serum p53 Antibody Levels Indicate Poor Prognosis in Patients with Colorectal Cancer. Br. J. Cancer 1998, 77, 1848-1851. [CrossRef] [PubMed]

12. Kunizaki, M.; Sawai, T.; Takeshita, H.; Tominaga, T.; Hidaka, S.; To, K.; Miyazaki, T.; Hamamoto, R.; Nanashima, A.; Nagayasu, T. Clinical Value of Serum p53 Antibody in the Diagnosis and Prognosis of Colorectal Cancer. Anticancer Res. 2016, 36, 4171-4175. [PubMed]

13. Kunizaki, M.; Fukuda, A.; Wakata, K.; Tominaga, T.; Nonaka, T.; Miyazaki, T.; Matsumoto, K.; Sumida, Y.; Hidaka, S.; Yasutake, T.; et al. Clinical Significance of Serum p53 Antibody in the Early Detection and Poor Prognosis of Gastric Cancer. Anticancer Res. 2017, 37, 1979-1984. [PubMed]

14. Murray, P.V.; Soussi, T.; O’Brien, M.E.; Smith, I.E.; Brossault, S.; Norton, A.; Ashley, S.; Tavassoli, M. Serum p53 Antibodies: Predictors of Survival in Small-Cell Lung Cancer? Br. J. Cancer 2000, 83, 1418-1424. [CrossRef]

15. Parasole, R.; Izzo, F.; Perrone, F.; Pignata, S.; Galati, M.G.; Leonardi, E.; Castiglione, F.; Orlando, R.; Castello, G.; Esposito, G.; et al. Prognostic Value of Serum Biological Markers in Patients with Hepatocellular Carcinoma. Clin. Cancer Res. 2001, 7, $3504-3509$.

16. Tokunaga, R.; Sakamoto, Y.; Nakagawa, S.; Yoshida, N.; Baba, H. The Utility of Tumor Marker Combination, Including Serum P53 Antibody, in Colorectal Cancer Treatment. Surg. Today 2017, 47, 636-642. [CrossRef]

17. Zalcman, G.; Trédaniel, J.; Schlichtholz, B.; Urban, T.; Milleron, B.; Lubin, R.; Meignin, V.; Couderc, L.J.; Hirsch, A.; Soussi, T. Prognostic Significance of Serum p53 Antibodies in Patients with Limited-Stage Small Cell Lung Cancer. Int. J. Cancer 2000, 89, 81-86. [CrossRef]

18. Kunizaki, M.; Hamasaki, K.; Wakata, K.; Tobinaga, S.; Sumida, Y.; Hidaka, S.; Yasutake, T.; Miyazaki, T.; Matsumoto, K.; Yamasaki, T.; et al. Clinical Value of Serum p53 Antibody in the Diagnosis and Prognosis of Esophageal Squamous Cell Carcinoma. Anticancer Res. 2018, 38, 1807-1813.

19. Takashi, S.; Satoshi, Y.; Akihiko, O.; Naoya, Y.; Yusuke, T.; Kentaro, M.; Yu, O.; Yasuaki, N.; Koichi, Y.; Takashi, F.; et al. Clinical Impact of Preoperative Serum p53 Antibody Titers in 1487 Patients with Surgically Treated Esophageal Squamous Cell Carcinoma: A Multi-Institutional Study. Esophagus 2021, 18, 65-71. [CrossRef] [PubMed] 
20. Okada, R.; Otsuka, Y.; Wakabayashi, T.; Shinoda, M.; Aoki, T.; Murakami, M.; Arizumi, S.; Yamamoto, M.; Aramaki, O.; Takayama, T.; et al. Six Autoantibodies as Potential Serum Biomarkers of Hepatocellular Carcinoma: A Prospective Multicenter Study. Int. J. Cancer 2020, 147, 2578-2586. [CrossRef] [PubMed]

21. Oshima, Y.; Suzuki, T.; Yajima, S.; Nanami, T.; Shiratori, F.; Funahashi, K.; Shimada, H. Serum p53 Antibody: Useful for Detecting Gastric Cancer but Not for Predicting Prognosis after Surgery. Surg. Today 2020, 50, 1402-1408. [CrossRef] [PubMed]

22. Mattioni, M.; Soddu, S.; Prodosmo, A.; Visca, P.; Conti, S.; Alessandrini, G.; Facciolo, F.; Strigari, L. Prognostic Role of Serum p53 Antibodies in Lung Cancer. BMC Cancer 2015, 15, 148. [CrossRef] [PubMed]

23. Suzuki, T.; Yajima, S.; Ishioka, N.; Nanami, T.; Oshima, Y.; Washizawa, N.; Funahashi, K.; Otsuka, S.; Nemoto, T.; Shimada, H. Prognostic Significance of High Serum p53 Antibody Titers in Patients with Esophageal Squamous Cell Carcinoma. Esophagus 2018, 15, 294-300. [CrossRef]

24. Mattioni, M.; Soddu, S.; Porrello, A.; D'Alessandro, R.; Spila, A.; Guadagni, F. Serum Anti-p53 Antibodies as a Useful Marker for Prognosis of Gastric Carcinoma. Int. J. Biol. Markers 2007, 22, 302-306. [CrossRef]

25. Goodell, V.; Salazar, L.G.; Urban, N.; Drescher, C.W.; Gray, H.; Swensen, R.E.; McIntosh, M.W.; Disis, M.L. Antibody Immunity to the p53 Oncogenic Protein Is a Prognostic Indicator in Ovarian Cancer. J. Clin. Oncol. 2006, 24, 762-768. [CrossRef]

26. Porzsolt, F.; Schmid, M.; Höher, D.; Muche, R.; Gaus, W.; Montenarh, M. Biologic Relevance of Auto-Anti Bodies against p53 in Patients with Metastatic Breast Cancer. Oncol. Res. Treatment 1994, 17, 402-408. [CrossRef]

27. Mantel, N.; Haenszel, W. Statistical Aspects of the Analysis of Data from Retrospective Studies of Disease. J. Natl. Cancer Inst. 1959, 22, 719-748. [PubMed]

28. DerSimonian, R.; Laird, N. Meta-Analysis in Clinical Trials Revisited. Contemp. Clin. Trials 2015, 45, 139-145. [CrossRef] 